\title{
What determines health-related quality of life among people living with HIV: an updated review of the literature
}

Sophie Degroote ${ }^{1,2^{*}}$, Dirk Vogelaers ${ }^{1,3}$ and Dominique M Vandijck ${ }^{1,2,4}$

\begin{abstract}
Background: As infection with the Human Immunodeficiency Virus (HIV) has evolved to a chronic disease, perceived health-related quality of life (HRQoL) is becoming a prominent and important patient-reported outcome measure in HIV care. Literature discusses different factors influencing HRQoL in this population, however, currently no consensus exists about the main determinants. In this review a clear, up-to-date overview of the determinants influencing HRQOL among people living with HIV is provided.
\end{abstract}

Methods: All studies published before July 2013 that identified determinants of HRQoL among people living with HIV in high-income countries, were considered in this narrative review. PubMed, Web of Science and The Cochrane Library were consulted using the keywords 'determinants', 'quality of life', 'HIV' and 'AIDS'. To be included, studies should have reported overall health and/or physical/mental health scores on a validated instrument and performed multivariable regression analyses to identify determinants that independently influence perceived HRQoL.

Results: In total, 49 studies were included for further analysis and they used a variety of HRQoL instruments: Medical Outcomes Study Short Form-36 or variants, Medical Outcomes Study-HIV, HIV Cost and Services Utilization Study measure, Multidimensional Quality of Life Questionnaire, HIV targeted quality of life instrument, Functional Assessment of Human Immunodeficiency Virus Infection, HIV Overview of Problems Evaluation System, EuroQol, Fanning Quality of Life scale, Health Index and PROQOL-HIV. In this review, the discussed determinants were thematically divided into socio-demographic, clinical, psychological and behavioural factors. Employment, immunological status, presence of symptoms, depression, social support and adherence to antiretroviral therapy were most frequently and consistently reported to be associated with HRQoL among people living with HIV.

Conclusions: HRQoL among people living with HIV is influenced by several determinants. These determinants independently, but simultaneously impact perceived HRQoL. Most HRQoL instruments do not capture all key determinants. We recommend that the choice for an instrument should depend on the purpose of the HRQoL assessment.

Keywords: HIV, Acquired immunodeficiency syndrome, Quality of life, Epidemiologic factors, Review

\footnotetext{
* Correspondence: SophieM.Degroote@UGent.be

${ }^{1}$ Department of General Internal Medicine, Infectious Diseases and

Psychosomatics, Ghent University Hospital, De Pintelaan 185, 9000 Ghent,

Belgium

${ }^{2}$ Department of Public Health, Faculty of Medicine and Health Sciences,

Ghent University, De Pintelaan 185, 9000 Ghent, Belgium

Full list of author information is available at the end of the article
} 


\section{Background}

Since the HAART (highly active antiretroviral therapy) era, HIV has been added to the increasing list of chronic diseases [1,2]. Still, daily and strict intake of antiretroviral medication is required to achieve or to maintain virological and immunological control [3,4]. However, these are not the only outcomes that should be taken into account. In chronic diseases, assessing health-related quality of life (HRQoL) has become an integral part of follow-up. HRQoL measurements provide valuable feedback about therapeutic interventions and they are indispensable in cost-effectiveness analyses [5]. HRQoL measures can also identify determinants of HRQoL among people living with HIV (PLHIV), which is vital to maximize HRQoL. Although different studies identified factors associated with HRQoL, there is no consensus about the main determinants. In addition, a variety of HRQoL instruments are currently being used in PLHIV. In this review, we examined determinants reported to be associated with HRQoL in PLHIV and we critically discuss the use of HRQoL instruments.

\section{Methods}

A narrative review was performed. The global search strategy was to search the databases PubMed, Web of Science and The Cochrane Library using the (Mesh) terms 'determinant(s)', 'quality of life', 'HIV', 'AIDS' as title words. Articles in this review are 1) investigating HRQoL in HIV-infected (adult) individuals 2) published prior to July 2013, 3) full text available in English, 4) conducted in high-income countries, 5) reporting HRQoL as one total score and/or as a physical and mental score, 6) using a validated HRQoL instrument and 7) applying quantitative methodology and multivariable regression analysis to identify determinants of HRQoL. Titles and abstracts were reviewed to verify those criteria. If all inclusion criteria were fulfilled or if this was still unclear, the manuscript was fully read. In case the full text revealed that not all requirements were present, the manuscript was still excluded from further consideration. Additional literature was obtained through searching references in the manuscripts (snowball method).

A priori, a framework with four categories of determinants was made: socio-demographic, clinical, psychological and behavioural determinants. Those categories were chosen by analogy with research on HRQoL performed in our hospital department. In particular, our research assesses three of the categories through a selfreport questionnaire, consisting of a sociodemographic part, a psychological part (assessment of depressive symptoms, social support, satisfaction with care) and a behavioural part (assessment of adherence and substance use). Clinical parameters on the other hand are assessed via the electronic patient record [6]. While reading and interpreting the manuscripts, the categories were further subdivided. Results and conclusions from manuscripts were then allocated to one or more determinants. The review was further elaborated by addressing every determinant separately and rereading all manuscripts that were relevant for that determinant.

In addition to the manuscript, an extensive table is provided in which methodological features (study design, sample, instrument) and main results of all included studies are provided (Additional File 1: Table S1).

\section{Results}

In total, 49 studies were included for further analysis. The instruments used to measure HRQoL were various: Medical Outcomes Study Short Form-36 or variants, Medical Outcomes Study-HIV, HIV Cost and Services Utilization Study measure, Multidimensional Quality of Life Questionnaire, HIV targeted quality of life instrument, Functional Assessment of Human Immunodeficiency Virus Infection, HIV Overview of Problems Evaluation System, EuroQol, Fanning Quality of Life scale, Health Index and PROQOL-HIV (Additional File 1: Table S1).

Determinants of HRQoL were divided into four categories: socio-demographic, clinical, psychological and behavioural factors. For purposes of intelligibility and conciseness, only determinants of overall health outcomes, as well as physical and mental health scores were commented. Factors associated with subscales of HRQoL were not discussed.

\section{Socio-demographic characteristics Gender}

There was no general agreement about gender differences in HRQoL [7]. If differences were found, women mostly reported lower HRQoL than men [8-10]. Different explanations were given: women would be more likely to report their unfavourable physical states than men because men are expected to adopt a more stoic attitude $[10,11]$, items on physical subscales would be different for men and women [10], and/or women would have more feelings of guilt [12]. Gender differences in HRQoL could also be a consequence of gender differences in mental illnesses. Mood disorders, anxiety disorders and psychosomatic disorders are more prevalent in females, possibly contributing to the HRQoL difference [11]. Controlling for clinical and socio-demographic factors could eliminate gender differences [7].

In contrast, some studies found that females had a better mental health [13] or reported better overall health [14]. Better coping strategies in females and a higher proportion of anxious men in that sample, respectively, were proposed as explanations for those findings. At last, Mrus and colleagues observed no difference towards overall health change between the genders and they 
suggested that health change, instead of health status, may be a better measure to evaluate HRQoL longitudinally [11].

\section{Age}

Older age was generally associated with lower physical health [13,15-19] and with a greater decline in physical health over time [9] most likely due to physical senescence. The relationship with mental health was less distinct. There could be a positive relationship between younger age and better mental health [19] while older age was associated with a decrease in mental health after six months in another study [20]. As most studies were not able to find any association, it seems that mental health is less age-dependent.

\section{Family situation}

A stable relationship conceivably contributes to a good HRQoL. This was shown, though only for physical health, in two studies [18,21]. Conflicting results were found with respect to changes in HRQoL over time. In women, being single was associated with an improvement in HRQoL after four months, whereas being married was associated with a decline [22]. Being chronically ill possibly causes more health distress and anxiety in married women, since the illness can interfere with their role as a spouse. However, a stable partner was also found to be positively associated with mental health after one year [9].

Concerning parenthood, a similar picture emerged. Children bring happiness, however, ill parents will be more worried about their health because of them. PLHIV may be more confronted with their constraints through the process of bringing up children [9]. Accordingly, in two studies, parenthood was negatively associated with physical health over time $[8,9]$.

\section{Socio-economic status: education, employment, income}

There was a joint consent that socio-economic status has an impact on HRQoL [9,14,15,17,18,20,23-27]. Employment influenced both physical and mental health status, or overall health $[14,17,23,24,28]$ although the effect on physical health was twice as big [25]. Employment was a positive predictor for good physical health after three to four years [26]. Employment constitutes a big part of the daily life of people. It can provide structure, a social support network, role identity and meaning [29]. The exact association between employment and HRQoL, however, remained unproven. Probably this is a bi-directional relationship: good HRQoL could be a requirement to be able to work (selection hypothesis), or work could be a source of well-being (causation hypothesis) [25,27].

There were indications for an association between financial situation and HRQoL $[15,18,23]$. A low versus middleor high income was associated with a lower mental and overall health [23]. Yet, income may be not the best measure to assess financial situation. Data concerning expenditures, family composition, financial insecurity and financial worries could provide useful additional information [30].

Education has also been linked to HRQoL and the relationship would be linear (i.e. higher education associated with higher HRQoL) [23]. An education of less than five years was negatively associated with mental health after six months [20] and with physical health change after 12 months [9]. It is possible that a lower education is a proxy of a lower socio-economic status in general, but it could also represent a poorer ability to understand the therapy recommendations [20]. This leads to less informed, less involved and less empowered patients which affects their HRQoL [31,32].

\section{Clinical and disease-related factors Virological and immunological status}

A better virological status was associated with a better overall [33], physical [14,18,34] and mental health [14], although a reasonable amount of studies did not find an (independent) association [8,13,15,20,27].

On the other hand, the relationship between immunological status and HRQoL was better corroborated by scientific evidence: a higher CD4-cell count was associated with a better physical health $[15,16,20,21,34,35]$. It was also a predictor for better physical health scores on follow-up measurements [20,36,37]. However, physical health improved more in patients who started ART at CD $4<200$ cells $/ \mu$ than in patients with $200-350$ cells $/ \mu \mathrm{l}$ or $>350$ cells $/ \mu \mathrm{l}$, because their physical health at baseline was worse [38]. Current guidelines recommend nonetheless to start ART early (i.e. 350-500 celles/ $\mu$ l), because there is evidence that this results in reduced progression to AIDS and reduced mortality [39]. In another study, CD4-count was negatively associated with HRQoL at baseline, but positively after 12 months [40]. It is possible that PLHIV with a high CD4-count at baseline wanted to go back to their excellent health and therefore considered their actual health status as dissatisfying. Over time, PLHIV develop other perceptions and expectations about HRQoL and may consider their health status acceptable [40].

Three studies have found an additional relationship with mental health. A lower CD4 cell count was then associated with a lower mental health score (MHS) (crosssectional and at 12 months) $[9,18,35]$. This could be due to the faster disease progression in PLHIV with low CD4counts, leading to distress [9].

\section{Staging and time since diagnosis}

Regarding disease stage, a clear effect on physical health has been established: as HIV evolves to a further stage, 
physical health diminishes. The poorest physical health is seen in people with AIDS $[18,23,25]$ and AIDS negatively influenced future physical health in follow-up studies $[9,26,36]$. In contrast, the effects on mental health were variable. A longer time since diagnosis was associated with both lower [14] and higher mental health [25]. A lower mental health over time could arise in cases where longitudinal follow-up resulted in a successful control of HIV. PLHIV may then experience difficulties to report mental problems because they are expected to feel fortunate because of their good health [14]. On the other hand, a longer duration could facilitate the development of effective coping strategies which could enhance mental health [40]. For health care providers, it is important to monitor mental health continuously, irrespective of the physical condition of the patient.

\section{ART}

The effect of ART on HRQoL has been described as a balance between reduced HIV-related symptoms and better life-expectancy on the one hand and medication side-effects on the other hand [41]. In people with an acceptable health status prior to ART-initiation, these side-effects could even overrule the benefits [21]. Encountering few ART-related side-effects contributed to normal physical and mental health [21]. Sexual dysfunction is an example of a side-effect - although frequently seen without iatrogenic cause - which was found to have a significant impact on HRQoL [42].

Recent studies mainly showed a positive effect of ART on HRQoL. This could be due to the continuous improvements in ART leading to less side-effects and to possibilities of combination preparations [43,44]. ART treatment was independently associated with a higher physical health [17] and interruption of ART treatment was associated with lower mental health [15]. In some studies, no HRQoL-differences between ART-treated and non-treated PLHIV were observed $[8,14,18]$, or only at bivariate level [20]. Maybe non-treated PLHIV had a better health, through which treatment was (still) not required [14].

\section{Presence of symptoms}

The negative influence of HIV-related symptoms on HRQoL was supported by scientific evidence and generally, a relationship with both physical and mental health was found $[20,23,25,26,28,45,46]$. Long-term studies found the same results $[9,36]$. In the HIV Cost and Services Utilisation Study, there was an inverse linear relation between number of symptoms and SF-36 scores. Each additional symptom (out of 13), was associated with a nearly 1.5-point decrease in physical and mental health [23]. Furthermore, symptom status was a stronger predictor for
HRQoL than functional status, health perceptions, age, sex, biological and physiological markers [47].

Lipodystrophy was found to be an influential HIVrelated symptom [48]. It affected both physical and mental health [48] and was associated with lower mental health after one year [9]. In time trade-off preference measurements, PLHIV would even give up a life year to avoid lipodystrophy [49]. It was although possible that HRQoL was affected only in PLHIV perceiving a moderate to severe body alteration [50]. Lipodystrophy is a highly visible symptom, and it could also affect the self-esteem and social contacts of PLHIV [48]. Similar negative effects of weight loss have been reported [14].

\section{Comorbidity}

A negative effect of comorbidity burden on HRQoL, especially on physical health, was supported by cross-sectional studies [15,51] and a longitudinal study [40]. Regarding specific comorbidity, comorbid hepatitis B was associated with a lower physical health and hepatitis $C$ negatively influenced physical health after one year [9]. On the other hand, HRQoL was the same among PLHIV, people infected with hepatitis $\mathrm{C}$ and people infected with both HIV and hepatitis C [17]. PLHIV with a GB virus C infection reported even a better quality of life than PLHIV without GB virus $C$ infection [52]. Authors reasoned that patients' HRQoL could be more affected by socio-economic and psychological factors than physical illnesses as HIV or hepatitis $C$, as the latter have become manageable diseases [17], or they may be a more favourable course of HIV infection in patients with $\mathrm{GB}$ virus $\mathrm{C}$ infection [52].

\section{Psychological factors \\ Depression and anxiety}

Depression strongly interferes with daily life and the negative impact on HRQoL was obvious $[8,46,53,54]$. Some authors did only find an association with mental health, and not with physical health $[9,15,16,55]$ although depression can also cause physical problems (e.g. less appetite, sleep disorders...). Not only the presence, but also a history of depression was associated with poorer HRQoL [17]. Depression also mediated the relationships between coping styles, social support and HRQoL [16,53], which will be discussed further on. The prevalence of anxiety disorders in PLHIV is higher than in the general population and it is known that anxiety is associated with depressive symptoms $[14,56]$. Anxiety was found to be associated with a diminished physical and mental health [18].

\section{Coping styles, locus of control and religion}

Coping styles are highly relevant in PLHIV, looking for example at the stress resulting from HIV diagnosis and treatment as well as multiple possible other stressors $[53,57]$. Studies examining the effect of coping styles on 
HRQoL have often found that the effect was indirect, namely via the intermediate determinant depression $[16,53]$. An active coping style has also been found to be directly associated with a better HRQoL $[35,40]$. People adopting an active coping style undertake actions to enhance their current state and this coping style is generally thought to be effective in reducing stress [58] and the impact of life stressors on mental health [19]. Coping styles are also associated with health locus of control (HLOC). People with an internal HLOC believe that health outcomes result directly from one's own behaviour whereas people with an external HLOC believe that others- other persons, fate, or luck- determine the outcome [59]. An internal HLOC was a predictor of a better physical health and a powerful others HLOC predicted a lower mental health [26]. However, somewhat contrary to that, a higher level of spirituality/religion (which could be associated with an external HLOC) has been found to be correlated with the perception of a better life then before the HIV diagnosis. It seems that religious/spiritual coping could also be an effective coping style [60]. Nevertheless, religious coping could be ineffective too, by arousing feelings of punishment by God, or being ostracised [61].

\section{Social support}

Social support could directly influence health outcomes, or it could serve as a buffer to reduce the influence of stressors on health outcomes [62]. Many studies have found positive relations between the presence of social support and both physical and mental health [13,25,53]. Furthermore, a higher social support at baseline was predictive for a better mental health after 12 months [40]. In the study of Jia et al. [53], social support had a mainly indirect role in HRQoL, mediated by depression. This suggests that enhancing social support could reduce depressive symptoms, which then could improve HRQoL.

It seemed that the more people PLHIV have to talk to (i.e. providing social support), the better the mental health was [15]. By studying different types of social support (emotional and tangible social support), Friedland et al. were able to distinguish different patterns [63]. Emotional social support (e.g. empathy, affection, caring) positively influenced HRQoL and tangible social support (e.g. financial and material assistance) negatively influenced HRQoL. People who received more tangible social support perceived themselves as more ill and as having a lower HRQoL [63]. Associations between social support and HRQoL over time seemed to vary. Possibly, social support becomes more important at difficult times [64].

\section{Neuropsychological status}

Cognitive problems lead to difficulties in every day practices, such as remembering names of new people, concentrating during a conversation or finding solutions for unexpected problems [65]. These will most probably affect HRQoL. In a study in HIV positive women, neurocognitive performance together with emotional distress accounted for most of the variance of HRQoL [66]. The validation study of the Quality of Well-being scale for HIV patients also revealed a significant influence of neurocognitive impairment [54]. In another study, neurocognitive impairment reduced physical health, but not mental health [55].

\section{Other (health care, disclosure, stigma)}

The way PLHIV perceive health care service has shown to be important for the patient's HRQoL $[18,20]$. Poor satisfaction with information from health care providers was independently associated with a lower mental health [20]. Inadequate communication with the physician could lead to misunderstanding, uncertainty and a lack of trust in the caregiver [20]. Therefore, communication is considered one of the core competencies of physicians [67]. Some PLHIV even experience rejection by the medical staff, especially people infected through drug use. Wrong attitudes could hinder a good physician-patient relationship, which is crucial for physical HRQoL [18]. Experiencing stigma negatively influenced HRQoL [28] and discrimination from family, friends or at work negatively influenced mental health [18]. Disclosing seropositive status was found to have negative effects on both physical and mental health [18]. The latter relationship, however, remained unclear, because disclosure could also be beneficial for the patient's mental and physical health (mainly through social support) [68]. However it could potentially be related to the fact that people with worse HRQoL have to disclose their seropositive status because of the symptoms, and may feel forced to do so instead of voluntarily doing so. PLHIV should be prepared and supported by health care professionals before their decision whether or not to disclose and before they are confronted with stigma and discrimination, in order to be able to better cope with these difficulties [46].

\section{Behavioural factors \\ Smoking}

The relationships between smoking and HRQoL was not extensively studied yet [69]. Two studies suggested that smoking negatively influenced HRQoL [16,69]. Among HIV-positive veterans, current smokers had the lowest HRQoL as compared to former and never smokers [69]. Current smokers were more at risk for pulmonary diseases and respiratory symptoms, which may affect their physical health [69]. However, smoking was also found to be negatively associated with mental health [16]. Psychiatric comorbidity was found to be highly prevalent in smokers - or the other way around, since patients 
reported that smoking helps them cope with depressive symptoms and anxiety [70].

\section{Alcohol use}

The effect of alcohol use on HRQoL in PLHIV was scarcely or only superficially studied [71]. In none of those studies among PLHIV, an independent association between alcohol use and HRQoL was found $[8,18,71]$ except for one. In that study, not using alcohol was a predictor for a lower physical health [15]. A causal relationship between light to moderate alcohol use and a better physical HRQoL is, however, not very plausible. Light to moderate alcohol use could rather be seen as an expression of risk behaviour for which a certain degree of functional status is required [15].

\section{Drug use}

Quality of life in HIV-positive drug users has been relatively more studied than in tobacco and alcohol users, because IDU is a risk factor for HIV-transmission. Current drug use was associated with lower mental health [15,71,72]. HRQoL in former users of illicit drugs was not worse than in persons who never used drugs [71]. For IDU the same was found: being an IDU was associated with a lower physical health [13], whereas being a former IDU was associated with a better physical and mental health [21]. Impact of drug use on HRQoL could be direct, via the physical deterioration caused by the drugs [13] or indirect, via associated psychiatric disorders [72].

\section{Adherence}

In a review of twelve studies considering the relationship between adherence to ART and HRQoL, ten showed an association with HRQoL [73]. Three of them applied a prospective design and were thus more indicative for a causal relationship [73]. More adherent PLHIV probably had better virological and immunological outcomes and could therefore have a better HRQoL.

Reporting concerns and difficulties about taking medication, was associated with poor mental health $[13,74]$. These difficulties could originate in a low self-efficacy, a high pill burden, difficulties to incorporate the medication moments in daily activities, experiencing side-effects...

\section{Life style and sexual risk behaviour}

Not surprisingly, physical activity was associated with a better physical health $[16,75,76]$. Healthy nutrition and a good stress management were associated with both physical and mental health [75]. Associations between unsafe sex and HRQoL were contradictory: in one study, there was no relationship to either physical or mental health and in another study [75], having unsafe sex with casual partners was associated with poor mental health [77].

\section{Discussion}

This review presents an overview of socio-demographic, clinical, psychological and behavioural factors associated with HRQoL in PLHIV. Many determinants have been found, and it is not clear which determinants are the strongest predictors for HRQoL. Nonetheless, there seems to be a consensus about the effect of socio-economic status, immunological status, presence of symptoms, (psychiatric) comorbidity, social support and adherence to ART.

These partly correspond to determinants of HRQoL of people living with other diseases. In patients with Crohn's

Table 1 Overview of HRQOL instruments used in the reviewed manuscripts

\begin{tabular}{|c|c|c|}
\hline Name of the instrument & $\begin{array}{l}\text { Generic or } \\
\text { HIV-specific } \\
\text { instrument }\end{array}$ & Measurements \\
\hline \multirow{3}{*}{$\begin{array}{l}\text { SF-36 (Medical Outcomes } \\
\text { Study Short Form-36 or } \\
\text { variants (SF-12, SF-8)) [88] }\end{array}$} & \multirow[t]{3}{*}{ Generic } & 8 subscales \\
\hline & & $\begin{array}{l}\text { Physical health } \\
\text { summary }\end{array}$ \\
\hline & & Mental health summary \\
\hline \multirow{3}{*}{$\begin{array}{l}\text { MOS-HIV (Medical } \\
\text { Outcomes Study-HIV) [89] }\end{array}$} & \multirow[t]{3}{*}{ HIV-specific } & 11 subscales \\
\hline & & Physical health score \\
\hline & & Mental health score \\
\hline \multirow{4}{*}{$\begin{array}{l}\text { HCSUS (HIV Cost and Services } \\
\text { Utilization Study tool) [90] }\end{array}$} & \multirow[t]{4}{*}{ HIV-specific } & 10 subscales \\
\hline & & Physical health \\
\hline & & Mental health \\
\hline & & Overall health \\
\hline \multirow{2}{*}{$\begin{array}{l}\text { MQoL-HIV (Multidimensional } \\
\text { Quality of Life Questionnaire } \\
\text { for people with HIV/AIDS) [91] }\end{array}$} & \multirow[t]{2}{*}{ HIV-specific } & 10 subscales \\
\hline & & Global score \\
\hline \multirow{2}{*}{$\begin{array}{l}\text { HAT-QOL (HIV targeted } \\
\text { quality of life instrument) [92] }\end{array}$} & \multirow[t]{2}{*}{ HIV-specific } & 9 subscales \\
\hline & & Global score \\
\hline \multirow{5}{*}{$\begin{array}{l}\text { FAHI (Functional Assessment } \\
\text { of Human Immunodeficiency } \\
\text { Virus Infection) [93] }\end{array}$} & \multirow[t]{5}{*}{ HIV-specific } & 4 subscales: \\
\hline & & Physical well-being \\
\hline & & Emotional well-being \\
\hline & & (Social well-being)* $^{*}$ \\
\hline & & (Functional well-being)* $^{*}$ \\
\hline \multirow{2}{*}{$\begin{array}{l}\text { HOPES (HIV Overview } \\
\text { of Problems Evaluation } \\
\text { System) [94] }\end{array}$} & \multirow[t]{2}{*}{ HIV-specific } & 6 subscales \\
\hline & & Global score \\
\hline EQ (EuroQol) [95] & Generic & Global score (utility) \\
\hline $\begin{array}{l}\text { Fanning Quality of Life } \\
\text { Scale [96] }\end{array}$ & HIV-specific & Global score \\
\hline \multirow[t]{2}{*}{ HI (Health Index) $[97,98]$} & \multirow[t]{2}{*}{ Generic } & Physical well-being \\
\hline & & Mental well-being \\
\hline \multirow[t]{3}{*}{ PROQOL [99] } & \multirow[t]{3}{*}{ HIV-specific } & 7 subscales \\
\hline & & (+ 1 on treatment impact) \\
\hline & & Global score \\
\hline
\end{tabular}

*Determinants of the FAHI-subscales 'social well-being' and 'functional well-being' were not considered in this review. 
disease, epilepsy, Parkinson's disease and aneurysmal subarachnoid haemorrhage, advanced disease stage (cfr. immunological status) was found to be predictive for impaired HRQoL [78-81]. Disability (cfr. presence of symptoms) was a determinant of HRQoL in patients with Crohn's disease, Parkinson's disease and aneurysmal subarachnoid haemorrhage [78-80]. Depression was negatively associated with HRQoL in patients with epilepsy, Parkinson's disease and aneurysmal subarachnoid haemorrhage [79-81]. Presence of comorbidities was associated with lower HRQoL in patients with epilepsy, lung cancer and in long-term survivors of colorectal cancer [81-83].

Literature about HRQoL in PLHIV consisted mostly of cross-sectional studies, however some longitudinal and interventional studies were found as well. Overall, there was a great diversity of instruments to measure HRQoL in PLHIV. Both generic (regularly SF-36) and diseasespecific (MOS-HIV, HCSUS, HAT-QOL ...) instruments were used (see Table 1). It is impossible to point out the best HRQoL instrument for PLHIV, since that choice mainly depends on the purpose of the assessment. For example, cost-effectiveness analyses require a HRQoL instrument that provides an index score while clinical routine management requires an instrument that provides information about HIV-specific aspects influencing HRQoL in PLHIV. Up till now, however, many HIV-specific instruments omit some of those aspects (e.g. stigma, coping and resilience, body image...) and literature concerning those determinants is rather scarce $[35,84,85]$. Instruments developed in cooperation with PLHIV (e.g. FAHI, HAT-QOL, HOPES, PROQOL) try to minimize that limitation. HRQoL instruments in PLHIV have been compared and discussed by many researchers, mainly by means of two-by-two comparisons in a selected population. Two studies provide a more general overview: Clayson et al. brought three generic (SF-36, EuroQol and Health Utilities Index) and two HIV-specific (MOS-HIV and FAHI) instruments forward as appropriate for use in clinical trials [86]. Their conclusions were based upon assessment of content, practicality and psychometric properties. Following their criteria, generic instruments should also be able to provide preference-based index scores and they should have normative population data. Grossman et al. suggest the SF-12 and MOS-HIV as the most appropriate tools [87]. They made a trade-off between the brevity of the instrument and the usefulness of the information provided.

The heterogeneity of HRQoL instruments was also present in the types and numbers of possible determinants that were analysed. Moreover, the detail by which these determinants were studied, varied from one single question to a whole battery of tests and interviews. Although this makes it difficult to compare results, it permits to 1) state that a certain factor is associated with
HRQoL, independently of many other variables and 2) describe this effect more profoundly.

This is a narrative review, and this method has several limitations. The literature search was not integrally documented, and is as such impossible to reproduce and the inclusion of the studies could be subject to personal bias. Nonetheless, we reported transparently about the search method and aimed at composing a review as complete and as consistent as possible. The latter is also the reason for including only papers that used quantitative, multivariable regression analyses. Thereby, we do not want to detract from the great value of papers using other methodologies (especially qualitative research).

\section{Conclusion}

HRQoL in PLHIV is influenced by many concurrent factors. From the evidence studied here we can conclude that there is a consensus about the influence of socio-economic status, immunological status, presence of symptoms, (psychiatric) comorbidity, social support and adherence to ART. Various instruments can be used to assess HRQoL in PLHIV, however, all have limitations. The choice of instrument should depend on the purpose of the HRQoL assessment.

\section{Additional file}

Additional File 1: Table S1: Overview of the included articles.

\section{Competing interests}

The authors declare that they have no competing interests.

\section{Authors' contributions}

SD participated in the design of the study, in the acquisition and interpretation of the data and drafted the manuscript. DV contributed to the conception of the study and critically revised the manuscript. DMV contributed to the design of the study and the interpretation of the data and critically revised the manuscript. All authors read and approved the final manuscript.

\section{Author details}

'Department of General Internal Medicine, Infectious Diseases and Psychosomatics, Ghent University Hospital, De Pintelaan 185, 9000 Ghent, Belgium. ${ }^{2}$ Department of Public Health, Faculty of Medicine and Health Sciences, Ghent University, De Pintelaan 185, 9000 Ghent, Belgium. ${ }^{3}$ Department of Internal Medicine, Faculty of Medicine and Health Sciences, Ghent University, De Pintelaan 185, 9000 Ghent, Belgium. ${ }^{4}$ Department of Economics, Faculty of Business Economics, Hasselt University, Agoralaan Building D, 3590 Diepenbeek, Belgium.

Received: 21 January 2014 Accepted: 13 August 2014 Published: 17 November 2014

\section{References}

1. Mocroft A, Vella S, Benfield TL, Chiesi A, Miller V, Gargalianos P, D'Arminio Monforte A, Yust I, Bruun JN, Phillips AN, Lundgren JD: Changing patterns of mortality across Europe in patients infected with HIV-1. Lancet 1998, 352:1725-1730.

2. Palella FJ, Delaney KM, Moorman AC, Loveless MO, Fuhrer J, Satten GA, Aschman DJ, Holmberg SD, Investigators HOS: Declining morbidity and mortality among patients with advanced human immunodeficiency virus infection. New Engl J Med 1998, 338:853-860. 
3. Paterson DL, Swindells S, Mohr J, Brester M, Vergis EN, Squier C, Wagener MM Singh N: Adherence to protease inhibitor therapy and outcomes in patients with HIV infection. Ann Intern Med 2000, 133:21-30.

4. Bangsberg DR, Hecht FM, Charlebois ED, Zolopa AR, Holodniy M, Sheiner L, Bamberger JD, Chesney MA, Moss A: Adherence to protease inhibitors, HIV-1 viral load, and development of drug resistance in an indigent population. Aids 2000, 14:357-366.

5. Kaplan RM, Ries AL: Quality of life: concept and definition. J Chron Obstruct Pulmon Dis 2007, 4:263-271.

6. Degroote S, Vogelaers DP, Vermeir P, Mariman A, De Rick A, Van Der Gucht B, Pelgrom J, Van Wanzeele F, Verhofstede C, Vandijck DM: Socio-economic, behavioural, (neuro)psychological and clinical determinants of HRQoL in people living with HIV in Belgium: a pilot study. J Int Aids Soc 2013, 16.

7. Perez $I R$, Lima $A O D L$, del Castillo $L S$, Bano JR, Ruz MAL, Jimenez AD: No differences in quality of life between men and women undergoing HIV antiretroviral treatment. Impact of demographic, clinical and psychosocial factors. Aids Care 2009, 21:943-952.

8. Briongos Figuero LS, Luque PB, Martin TP, Sagrado MG, Bouza JME: Assessment of factors influencing health-related quality of life in HIV-infected patients. HIV Med 2011, 12:22-30

9. Protopopescu C, Marcellin F, Spire B, Preau M, Verdon R, Peyramond D, Raffi F, Chene G, Leport C, Carrieri MP: Health-related quality of life in HIV-1-infected patients on HAART: a five-years longitudinal analysis accounting for dropout in the APROCO-COPILOTE cohort (ANRS CO-8). Qual Life Res 2007, 16:577-591.

10. Rao D, Hahn EA, Cella D, Hernandez L: The health related quality of life outcomes of English and Spanish speaking persons living with HIV/AIDS from the Continental United States and Puerto Rico. Aids Patient Care St 2007, 21:339-346.

11. Mrus JM, Williams PL, Tsevat J, Cohn SE, Wu AW: Gender differences in health-related quality of life in patients with HIV/AIDS. Qual Life Res 2005, 14:479-491.

12. Cederfjall C, Langius-Eklof A, Lidman K, Wredling R: Gender differences in perceived health-related quality of life among patients with HIV infection. Aids Patient Care St 2001, 15:31-39.

13. Ruiz Perez I, Rodriguez Baño J, Lopez Ruz MA, del Arco Jimenez A, Causse Prados M, Pasquau Liaño J, Martin Rico P, de la Torre Lima J, Prada Pardal J, Lopez Gomez M, Muñoz N, Morales D, Marcos M: Health-related quality of life of patients with HIV: Impact of sociodemographic, clinical and psychosocial factors. Qual Life Res 2005, 14:1301-1310.

14. Zinkernagel C, Taffé $P$, Rickenbach $M$, Amiet $R$, Ledergerber B, Volkart AC, Rauchfleisch U, Kiss A, Werder V, Vernazza P, Battegay M, Swiss HIV Cohort Study: Importance of mental health assessment in HIV-infected outpatients. J Acquir Immune Defic Syndr 2001, 28:240-249.

15. Liu CL, Johnson L, Ostrow D, Silvestre A, Visscher B, Jacobson LP: Predictors for lower quality of life in the HAART era among HIV-infected men. Jaids-J Aca Imm Def 2006, 42:470-477.

16. Kowal J, Overduin LY, Balfour L, Tasca GA, Corace K, Cameron DW: The role of psychological and behavioral variables in quality of life and the experience of bodily living with HIV. J Pain Symptom Manag 2008, 36:247-258.

17. Fleming CA, Christiansen D, Nunes D, Heeren T, Thornton D, Horsburgh CR, Koziel MJ, Graham C, Craven DE: Health-related quality of life of patients with HIV disease: Impact of hepatitis C coinfection. Clin Infect Dis 2004, 38:572-578.

18. Preau M, Marcellin F, Carrieri MP, Lert F, Obadia Y, Spire B: Health-related quality of life in French people living with HIV in 2003: results from the national ANRS-EN12-VESPA Study. Aids 2007, 21:S19-S27.

19. Gibson K, Rueda S, Rourke SB, Bekele T, Gardner S, Fenta H, Hart TA, Ohtn Cohort S: Mastery and coping moderate the negative effect of acute and chronic stressors on mental health-related quality of life in HIV. AIDS Patient Care STDS 2011, 25:371-381.

20. Murri R, Fantoni M, Del Borgo C, Visona R, Barracco A, Zambelli A, Testa L, Orchi N, Tozzi $V$, Bosco O, Wu AW: Determinants of health-related quality of life in HIV-infected patients. Aids Care 2003, 15:581-590.

21. Preau M, Protopopescu C, Spire B, Sobel A, Dellamonica P, Moatti JP, Carrieri MP: Health related quality of life among both current and former injection drug users who are HIV-infected. Drug Alcohol Depen 2007, 86:175-182

22. Sarna L, van Servellen G, Padilla G, Brecht ML: Quality of life in women with symptomatic HIV/AIDS. J Adv Nurs 1999, 30:597-605.
23. Hays RD, Cunningham WE, Sherbourne CD, Wilson IB, Wu AW, Cleary PD, McCaffrey DF, Fleishman JA, Crystal S, Collins R, Eggan F, Shapiro MF, Bozzette SA: Health-related quality of life in patients with human immunodeficiency virus infection in the United States: results from the HIV cost and services utilization study. Am J Med 2000, 108:714-722.

24. Blalock AC, Stephen Mcdaniel J, Farber EW: Effect of employment on quality of life and psychological functioning in patients with HIV/AIDS. Psychosomatics 2002, 43:400-404.

25. Rueda S, Raboud J, Mustard C, Bayoumi A, Lavis JN, Rourke SB: Employment status is associated with both physical and mental health quality of life in people living with HIV. Aids Care 2011, 23:435-443.

26. Preau M, Vincent $E$, Spire B, Reliquet $V$, Fournier I, Michelet C, Leport C, Morin M, Grp AS: Health-related quality of life and health locus of control beliefs among HIV-infected treated patients. J Psychosom Res 2005, 59:407-413.

27. Worthington $\mathrm{C}$, Krentz HB: Socio-economic factors and health-related quality of life in adults living with HIV. Int J Std Aids 2005, 16:608-614.

28. Herrmann S, McKinnon E, Hyland NB, Lalanne C, Mallal S, Nolan D, Chassany $\mathrm{O}$, Duracinsky M: HIV-related stigma and physical symptoms have a persistent influence on health-related quality of life in Australians with HIV infection. Health Qual Life Out 2013, 11.

29. Hoffman MA: HIV disease and work: effect on the individual, workplace, and interpersonal contexts. J Vocat Behav 1997, 51:163-201.

30. Park-Wyllie LY, Strike CS, Antoniou T, Bayoumi AM: Adverse quality of life consequences of antiretroviral medications. Aids Care 2007, 19:252-257.

31. Moattari M, Ebrahimi M, Sharifi N, Rouzbeh J: The effect of empowerment on the self-efficacy, quality of life and clinical and laboratory indicators of patients treated with hemodialysis: a randomized controlled trial. Health Qual Life Out 2012, 10

32. Pibernik-Okanovic M, Prasek M, Poljicanin-Filipovic T, Pavlic-Renar L, Metelko Z: Effects of an empowerment-based psychosocial intervention on quality of life and metabolic control in type 2 diabetic patients. Patient Educ Couns 2004, 52:193-199.

33. Schroecksnadel K, Sarcletti M, Winkler C, Mumelter B, Weiss G, Fuchs D, Kemmler G, Zangerle R: Quality of life and immune activation in patients with HIV-infection. Brain Behav Immun 2008, 22:881-889.

34. Call SA, Klapow JC, Stewart KE, Westfall AO, Mallinger AP, DeMasi RA, Centor R, Saag MS: Health-related quality of life and virologic outcomes in an HIV clinic. Qual Life Res 2000, 9:977-985.

35. Armon C, Lichtenstein $\mathrm{K}$ : The associations among coping, nadir CD4+ T-cell count, and non-HIV-related variables with health-related quality of life among an ambulatory HIV-positive patient population. Qual Life Res 2012, 21:993-1003.

36. Lorenz KA, Cunningham WE, Spritzer KL, Hays RD: Changes in symptoms and health-related quality of life in a nationally representative sample of adults in treatment for HIV. Qual Life Res 2006, 15:951-958.

37. Jia HG, Uphold CR, Wu S, Chen GJ, Duncan PW: Predictors of changes in health-related quality of life among men with HIV infection in the HAART era. Aids Patient Care St 2005, 19:395-405.

38. Nieuwkerk PT, Hillebrand-Haverkort ME, Vriesendorp R, Frissen PH, de Wolf F, Sprangers MA, Group AS: Quality of life after starting highly active antiretroviral therapy for chronic HIV-1 infection at different CD4 cell counts. J Acquir Immune Defic Syndr 2007, 45:600-601.

39. WHO Guidelines http://www.who.int/hiv/pub/guidelines/en/.

40. Jia HG, Uphold CR, Zheng Y, Wu S, Chen GJ, Findley K, Duncan PW: A further investigation of health-related quality of life over time among men with HIV infection in the HAART era. Qual Life Res 2007, 16:961-968.

41. Liu CL, Ostrow D, Detels R, Hu Z, Johnson L, Kingsley L, Jacobson LP: Impacts of HIV infection and HAART use on quality of life. Qual Life Res 2006, 15:941-949.

42. Koole O, Noestlinger C, Colebunders R: Quality of life in HIV clinical trials: Why sexual health should not be ignored. Plos Clin Trials 2007, 2.

43. Este JA, Cihlar T: Current status and challenges of antiretroviral research and therapy. Antivir Res 2010, 85:25-33.

44. Airoldi M, Zaccarelli M, Bisi L, Bini T, Antinori A, Mussini C, Bai F, Orofino G, Sighinolfi L, Gori A, Suter F, Maggiolo F: One-pill once-a-day HAART: a simplification strategy that improves adherence and quality of life of HIV-infected subjects. Patient Prefer Adherence 2010, 4:115-125.

45. Murri R, Ammassari A, Fantoni M, Scoppettuolo G, Cingolani A, De Luca A, Damiano F, Antinori A: Disease-related factors associated with health-related quality of life in people with nonadvanced HIV disease assessed using an 
Italian version of the MOS-HIV Health Survey. J Acq Immun Def Synd 1997, 16:350-356.

46. Holzemer WL, Human S, Arudo J, Rosa ME, Hamilton MJ, Corless I, Robinson L, Nicholas PK, Wantland DJ, Moezzi S, Willard S, Kirksey K, Portillo C, Sefcik E, Rivero-Méndez M, Maryland M: Exploring HIV stigma and quality of life for persons living with HIV infection. J Assoc Nurse Aids C 2009, 20:161-168.

47. Sousa KH, Holzemer WL, Henry SB, Slaughter R: Dimensions of health-related quality of life in persons living with HIV disease. J Adv Nurs 1999. 29:178-187.

48. Rajagopalan R, Laitinen D, Dietz B: Impact of lipoatrophy on quality of life in HIV patients receiving anti-retroviral therapy. Aids Care 2008, 20:1197-1201.

49. Lenert LA, Feddersen M, Sturley A, Lee D: Adverse effects of medications and trade-offs between length of life and quality of life in human immunodeficiency virus infection. Am J Med 2002, 113:229-232.

50. Guaraldi G, Murri R, Orlando G, Squillace N, Stentarelli C, Zona S, Garlassi E, Martinez E: Lipodystrophy and quality of life of HIV-infected persons. Aids Rev 2008, 10:152-161.

51. Rodriguez-Penney AT, ludicello JE, Riggs PK, Doyle K, Ellis RJ, Letendre SL, Grant I, Woods SP, Group HIVNRPH: Co-morbidities in persons infected with HIV: increased burden with older age and negative effects on health-related quality of life. AIDS Patient Care STDS 2013, 27:5-16.

52. Tillmann HL, Manns MP, Claes C, Heiken H, Schmidt RE, Stoll M: GB virus C infection and quality of life in HIV-positive patients. Aids Care 2004, 16:736-743.

53. Jia HG, Uphold CR, Wu S, Reid K, Findley K, Duncan PW: Health-related quality of life among men with HIV infection: effects of social support, coping, and depression. Aids Patient Care St 2004, 18:594-603.

54. Kaplan RM, Anderson JP, Patterson TL, Mccutchan JA, Weinrich JD, Heaton RK Atkinson JH, Thal L, Chandler J, Grant I: Validity of the quality of well-being scale for persons with human-immunodeficiency-virus infection. Psychosom Med 1995, 57:138-147.

55. Trepanier LL, Rourke SB, Bayoumi AM, Halman MH, Krzyzanowski S, Power C: The impact of neuropsychological impairment and depression on health-related quality of life in HIV-infection. J Clin Exp Neuropsyc 2005, 27:1-15.

56. Bing EG, Burnam MA, Longshore D, Fleishman JA, Sherbourne CD, London AS, Turner BJ, Eggan F, Beckman R, Vitiello B, Morton SC, Orlando M, Bozzette SA, Ortiz-Barron L, Shapiro M: Psychiatric disorders and drug use among human immunodeficiency virus-infected adults in the United States. Arch Gen Psychiatry 2001, 58:721-728.

57. Whetten K, Reif S, Whetten R, Murphy-McMillan LK: Trauma, mental health, distrust, and stigma among HIV-positive persons: implications for effective care. Psychosom Med 2008, 70:531-538.

58. Carroll L: Active coping. In Book Active Coping; 2013.

59. Rotter JB CJ, Phares EJ: Applications of a social learning theory of personality. New York: Holt, Rinehart and Winston; 1972.

60. Siegel K, Schrimshaw EW: The perceived benefits of religious and spiritual coping among older adults living with HIV/AIDS. J Sci Stud Relig 2002, 41:91-102.

61. Szaflarski M, Ritchey PN, Leonard AC, Mrus JM, Peterman AH, Ellison CG, McCullough ME, Tsevat J: Modeling the effects of spirituality/religion on patients' perceptions of living with HIV/AIDS. J Gen Intern Med 2006, 21:S28-S38.

62. Cobb S: Social support as a moderator of life stress. Psychosom Med 1976, 38:300-314.

63. Friedland J, Renwick R, McColl MM: Coping and social support as determinants of quality of life in HIV/AIDS. Aids Care 1996, 8:15-31.

64. Burgoyne R, Renwick R: Social support and quality of life over time among adults living with HIV in the HAART era. Soc Sci Med 2004, 58:1353-1366.

65. Grant I: Neurocognitive disturbances in HIV. Int Rev Psychiatr 2008, 20:33-47.

66. Osowiecki DM, Cohen RA, Morrow KM, Paul RH, Carpenter CCJ, Flanigan T, Boland RJ: Neurocognitive and psychological contributions to quality of life in HIV-1-infected women. Aids 2000, 14:1327-1332.

67. Porcel JM, Casademont J, Conthe P, Pinilla B, Pujol R, Garcia-Alegria J: Core competencies in internal medicine. Eur J Intern Med 2012, 23:338-341.

68. Serovich JM: A test of two HIV disclosure theories. Aids Educ Prev 2001, 13:355-364.

69. Crothers K, Griffith TA, McGinnis KA, Rodriguez-Barradas MC, Leaf DA, Weissman S, Gibert CL, Butt AA, Justice AC: The impact of cigarette smoking on mortality, quality of life, and comorbid illness among HIV-positive veterans. J Gen Intern Med 2005, 20:1142-1145.
70. Shuter J, Bernstein SL, Moadel AB: Cigarette smoking behaviors and beliefs in persons living With HIV/AIDS. Am J Health Behav 2012, 36:75-85.

71. Korthuis PT, Zephyrin LC, Fleishman JA, Saha S, Josephs JS, McGrath MM, Hellinger J, Gebo KA, Network HR: Health-related quality of life in HIV-infected patients: the role of substance use. Aids Patient Care St 2008, 22:859-867.

72. Sherbourne CD, Hays RD, Fleishman JA, Vitiello B, Magruder KM, Bing EG, McCaffrey D, Burnam A, Longshore D, Eggan F, Bozzette SA, Shapiro MF: Impact of psychiatric conditions on health-related quality of life in persons with HIV infection. Am J Psychiat 2000, 157:248-254.

73. Geocze L, Mucci S, De Marco MA, Nogueira-Martins LA, Citero VD: Quality of life and adherence to HAART in HIV-infected patients. Rev Saude Pub/ 2010, 44:743-749.

74. Corless IB, Voss J, Guarino AJ, Wantland D, Holzemer W, Jane Hamilton M, Sefcik E, Willard S, Kirksey K, Portillo C, Rivero Mendez M, Rosa ME, Nicholas PK, Human S, Maryland M, Moezzi S, Robinson L, Cuca Y: The impact of stressful life events, symptom status, and adherence concerns on quality of life in people living with HIV. J Assoc Nurses AIDS Care 2013, 24(6):478-90.

75. Uphold CR, Holmes W, Reid K, Findley K, Parada JP: Healthy lifestyles and health-related quality of life among men living with HIV infection. J Assoc Nurse Aids C 2007, 18:54-66.

76. O'Brien K, Nixon S, Tynan AM, Glazier R: Aerobic exercise interventions for adults living with HIV/AIDS. Cochrane Database Syst Rev 2010, CD001796.

77. Bouhnik AD, Preau M, Schiltz MA, Peretti-Watel P, Obadia Y, Lert F, Spire B: Unsafe sex with casual partners and quality of life among HIV-infected gay men: Evidence from a large representative sample of outpatients attending French hospitals (ANRS-EN12-VESPA). Jaids-J Acq Imm Def 2006, 42:597-603.

78. van der Have M, van der Aalst KS, Kaptein AA, Leenders M, Siersema PD, Oldenburg B, Fidder HH: Determinants of health-related quality of life in Crohn's disease: a systematic review and meta-analysis. J Crohns Colitis 2014, 8:93-106.

79. Passier PECA, Visser-Meily JMA, Rinkel GJE, Lindeman E, Post MWM: Determinants of health-related quality of life after aneurysmal subarachnoid hemorrhage: a systematic review. Qual Life Res 2013, 22:1027-1043.

80. Soh SE, Morris ME, McGinley JL: Determinants of health-related quality of life in Parkinson's disease: a systematic review. Parkinsonism Relat D 2011, 17:1-9.

81. Taylor RS, Sander JW, Taylor RJ, Baker GA: Predictors of health-related quality of life and costs in adults with epilepsy: a systematic review. Epilepsia 2011, 52:2168-2180.

82. Jansen $L$, Koch $L$, Brenner $H$, Arndt V: Quality of life among long-term ( $>=5$ years) colorectal cancer survivors - Systematic review. Eur J Cancer 2010, 46:2879-2888.

83. Poghosyan H, Sheldon LK, Leveille SG, Cooley ME: Health-related quality of life after surgical treatment in patients with non-small cell lung cancer: a systematic review. Lung Cancer-J las/c 2013, 81:11-26.

84. Farber EW, Schwartz JAJ, Schaper PE, Moonen DJ, McDaniel JS: Resilience factors associated with adaptation to HIV disease. Psychosomatics 2000, 41:140-146.

85. Yu XN, Lau JTF, Mak WWS, Cheng YM, LV YH, Zhang JX: A pilot theorybased intervention to improve resilience, psychosocial well-being, and quality of life among people living with HIV in Rural China. J Sex Marital Ther 2014, 40:1-16.

86. Clayson DJ, Wild DJ, Quarterman P, Duprat-Lomon I, Kubin M, Coons SJ: A comparative review of health-related quality-of-life measures for use in HIV/AIDS clinical trials. Pharmacoeconomics 2006, 24:751-765.

87. Grossman H, Sullivan P, Wu A: Quality of life and HIV: current assessment tools and future directions for clinical practice. AIDS Reader 2003, 13:583-90.

88. Ware JE Jr, Sherbourne CD: The MOS 36-item short-form health survey (SF-36). I. Conceptual framework and item selection. Med Care 1992, 30:473-483.

89. Wu AW, Revicki DA, Jacobson D, Malitz FE: Evidence for reliability, validity and usefulness of the Medical Outcomes Study HIV Health Survey (MOS-HIV). Qual Life Res 1997, 6:481-493.

90. Frankel MR, Shapiro MF, Duan N, Morton SC, Berry SH, Brown JA, Burnam MA, Cohn SE, Goldman DP, McCaffrey DF, Smith SM, St Clair PA, Tebow JF, Bozzette SA: National probability samples in studies of low-prevalence diseases. Part II: Designing and implementing the HIV cost and services utilization study sample. Health Serv Res 1999, 34:969-992. 
91. Kemmler G, Schmied B, Shetty-Lee A, Zangerle R, Hinterhuber H, Schussler G, Mumelter B: Quality of life of HIV-infected patients: psychometric properties and validation of the German version of the MQOL-HIV. Qual Life Res 2003, 12:1037-1050.

92. Holmes WC, Shea JA: A new HIV/AIDS-targeted quality of life (HAT-QoL) instrument: development, reliability, and validity. Med Care 1998, 36:138-154.

93. Peterman AH, Cella D, Mo F, McCain N: Psychometric validation of the revised Functional Assessment of Human Immunodeficiency Virus Infection (FAHI) quality of life instrument. Qual Life Res 1997, 6:572-584.

94. Schag CA, Ganz PA, Kahn B, Petersen L: Assessing the needs and quality of life of patients with HIV infection: development of the HIV Overview of Problems-Evaluation System (HOPES). Qual Life Res 1992, 1:397-413.

95. Group EQ: EuroQol - a new facility for the measurement of health-related quality of life. Health Policy 1990, 19:199-208.

96. Fanning MM, Emmott S: Evaluation of a Quality-of-Life Instrument for Hiv Aids. Aids Patient Care 1993, 7:161-162.

97. Nordstrom G, Nyman CR, Theorell T: Psychosocial adjustment and general state of health in patients with ileal conduit urinary diversion. Scand J Urol Nephrol 1992, 26:139-147.

98. Forsberg C, Bjorvell H, Cedermark B: Well-being and its relation to coping ability in patients with colo-rectal and gastric cancer before and after surgery. Scand J Caring Sci 1996, 10:35-44.

99. Duracinsky M, Herrmann S, Berzins B, Armstrong AR, Kohli R, Le Coeur S, Diouf A, Fournier I, Schechter M, Chassany O: The development of PROQOL-HIV: an international instrument to assess the health-related quality of life of persons living with HIV/AIDS. Jaids-J Aca Imm Def 2012, 59:498-505.

doi:10.1186/2049-3258-72-40

Cite this article as: Degroote et al: What determines health-related quality of life among people living with HIV: an updated review of the literature. Archives of Public Health 2014 72:40.

\section{Submit your next manuscript to BioMed Central and take full advantage of:}

- Convenient online submission

- Thorough peer review

- No space constraints or color figure charges

- Immediate publication on acceptance

- Inclusion in PubMed, CAS, Scopus and Google Scholar

- Research which is freely available for redistribution 